\title{
Jurist-Diction
}

Volume 4 No. 5 September 202

\section{Fungsi Jaminan Sebagai Penentu Credit Scoring Dalam Layanan Pinjam Meminjam Uang Berbasis Teknologi Informasi}

\author{
Nalendra Pradipto \\ dionalendra@gmail.com \\ Universitas Airlangga
}

\author{
How to cite: \\ Nalendra Pradipto, 'Fungsi \\ Jaminan Sebagai Penentu \\ Credit Scoring Dalam Layanan \\ Pinjam Meminjam Uang \\ Berbasis Teknologi Informasi' \\ (2021) Vol. 4 No. 5 Jurist- \\ Diction. \\ Histori artikel: \\ Submit 9 Juli 2021; \\ Diterima 15 Agustus 2021; \\ Diterbitkan 1 September 2021. \\ DOI: \\ 10.20473/jd.v4i5.29823 \\ p-ISSN: 2721-8392 \\ e-ISSN: $2655-8297$
}

\begin{abstract}
The growth of information technology or commonly referred to as Industrial Revolution 4.0 has given birth to a new idea namely Money Lending and Borrowing Services based on Information Technology. Peer to Peer Lending (P2P) Lending is a service that is much in demand by the public. The majority of $P 2 P$ Lending financial technology providers do not require collateral. With this condition, OJK has issued a special regulation, namely POJK No. 77 / POJK.01 / 2016 concerning Money Lending and Borrowing Services based on Information Technology. Article 21 POJK No.77 / POJK.01/2016 states that the Operator is required to manage credit risk and operational risk. One risk management undertaken by the Provider is to use Credit Scoring to classify Debtors into certain risk grades. However, because the majority of $P 2 P$ Lending does not require a material guarantee, the Credit Scoring factor other than collateral becomes very important. In practice, the Operator is often less selective about the classification of Debtors in Credit Scoring, resulting in many defaults.

Keywords: Peer to Peer Lending; Financial Technology; Credit Scoring; Risk Grade.
\end{abstract}

\begin{abstract}
Abstrak
Perkembangan teknologi informasi informasi atau yang biasa disebut dengan Revolusi Industri4.0 telah melahirkan gagasan baruyaitu Layanan Meminjam Uang Berbasis Teknologi Informasi. Peer to Peer Lending (P2P) Lending menjadi layanan yang banyak diminati oleh masyarakat. Dari beragam Penyelenggara teknologi finansial P2P Lending mayoritas tidak mensyaratkan adanya jaminan kebendaan. Dengan adanya kondisi tersebut OJK telah mengeluarkan aturan khusus yaitu POJK No. 77/ POJK.01/2016 tentang Layanan Pinjam Meminjam Uang Berbasis Teknologi Informasi. Pasal 21 POJK No.77/POJK.01/2016 menyatakan Penyelenggara wajib melakukan manajemen risiko kredit dan risiko operasional. Salah satu manajemen risiko yang dilakukan Penyelenggara adalah menggunakan Credit Scoring untuk mengklasifikasi Debitor ke dalam risk grade tertentu. Meskipun demikian karena mayoritas P2P Lending tidak mensyaratkan adanya jaminan kebendaan, maka faktor Credit Scoring selain jaminan menjadi sangat penting. Pada prakteknya Penyelenggara seringkali kurang selektif terhadap klasifikasi Debitor dalam Credit Scoring sehingga banyak terjadi wanprestasi.

Kata Kunci: Peer to Peer Lending; Teknologi Finansial; Credit Scoring; Risk Grade.
\end{abstract}




\section{Pendahuluan}

Perkembangan teknologi informasi atau saat ini disebut dengan Revolusi Industri 4.0 telah melahirkan sebuah gagasan baru yaitu layanan pinjam meminjam uang berbasis teknologi informasi atau biasa disebut dengan Financial Technology (selanjutnya disingkat fintech). Fintech adalah teknologi yang membangun sistem, menilai, dan memproses produk keuangan seperti obligasi, saham, kontrak, dan uang. Dalam arti sempit produk keuangan dapat dimakanai sebagai harga, waktu dan kredit. ${ }^{1}$ Dengan kehadiran fintech ini, masyarakat menjadi lebih mudah untuk melakukan pinjaman, karena dapat dilakukan secara online melalui gadget dan tidak harus lagi datang ke Bank maupun lembaga keuangan lainnya. Perbedaan yang paling signifikan dari pinjam meminjam uang berbasis teknologi informasi adalah syarat pinjaman yang tidak banyak, sehingga Debitor lebih mudah untuk mendapatkan pinjaman uang.

Dari kemudahan tersebut, Industri fintech saat ini sedang berkembang dengan pesat. Hal ini ditandai dengan semakin banyak berdirinya startup di bidang fintech. Fintech menawarkan berbagai jenis jasa keuangan, antara lain peer to peer ( $\mathrm{P} 2 \mathrm{P})$ lending (peminjaman), crowd funding, payment gateway (alat pembayaran), dan manajemen investasi. Dari beberapa jenis usaha tersebut, layanan P2P Lending dan sistem pembayaran yang paling banyak digunakan oleh masyarakat. Kegiatan P2P Lending merupakan praktik peminjaman uang kepada individu atau perusahaan melalui online. Website penyelenggara P2P Lending ibaratnya seperti sebuah marketplace lending yang akan mempertemukan antara pemberi pinjaman dengan penerima pinjaman melalui platform yang disediakan. Kegiatan P2P Lending setidaknya melibatkan tiga pihak yaitu penerima pinjaman, pemberi pinjaman dan penyelenggara. ${ }^{2}$ Kegiatan ini tidak hanya berguna sebagai tempat berinvestasi para pemberi pinjaman, melainkan sebuah solusi untuk masyarakat yang ingin mengembangkan usahanya namun membutuhkan modal.

\footnotetext{
${ }^{1}$ Freedman Roy S., Introduction to Financial Technology (Elsevier 2006).[22].

${ }^{2}$ Candrika Radita, 'Tanggung Gugat Penyelenggara Peer to Peer Lending Jika Penerima Pinjaman Melakukan Wanprestasi’ (2018) 1 Jurist-Diction.[2].
} 
Selain memberi pinjaman untuk modal bisnis, layanan P2P Lending juga dapat meminjamkan dana untuk kebutuhan pribadi.

Di Indonesia sendiri, fintech juga telah berkembang, meskipun masih tertinggal jika dibandingkan dengan negara lain seperti China, Hong Kong dan India. Saat ini, berdasarkan data yang dikeluarkan oleh perusahaan konsultan manajemen bisnis McKinsey \& Company dalam laporan terbarunya berjudul Digital Banking in Indonesia: Building Loyalty and Generating Growth, tingkat penetrasi penggunaan layanan keuangan melalui fintech di Indonesia masih sekitar 5\%. Angka tersebut tersebut jauh lebih rendah dibandingkan dengan negara China dengan presentasi 67\%, Hong Kong 57\% dan India 39\%. Meskipun demikian, fintech di Indonesia tetap mempunyai potensi besar untuk lebih berkembang kedepannya, karena berdasarkan survei yang dilakukan pada tahun 2017, pertumbuhan digitalisasi di Indonesia menjadi salah yang tercepat di dunia, bahkan mengalahkan China dan Brazil. ${ }^{3}$

Saat ini di Indonesia terdapat 164 Perusahaan fintech lending yang memiliki izin dan terdaftar di Otoritas Jasa Keuangan. ${ }^{4}$ Meskipun demikian, di Indonesia masih banyak terdapat fintech yang tidak memiliki izin dan tidak terdaftar di Otoritas Jasa Keuangan. Berdasarkan data dari Otoritas Jasa Keuangan hingga 2019 terdapat total 1494 Entitas fintech P2P Lending Illegal yang dihentikan oleh Satgas Waspada Investasi. ${ }^{5}$ Berdasarkan data tersebut banyak fintech yang tidak mensyaratkan adanya jaminan kebendaan dalam sebuah pinjaman, sehingga pinjaman dapat dilakukan oleh Debitor tanpa harus menjaminkan harta bendanya bagi Kreditor sebagai jaminan pelunasan utang.

Berkembangnya fintech P2P Lending tersebut, melahirkan sebuah Asosiasi khusus Penyelenggara Layanan Pinjam Meminjam Uang Berbasis Teknologi

\footnotetext{
${ }^{3}$ Abdul Rasyid, 'Sekilas Perkembangan Fintech di Indonesia', <www.law.binus.ac.id>, dikunjungi pada 25 Juni 2019.

${ }_{4}^{4}$ Otoritas Jasa Keuangan, 'Penyelenggara Fintech Terdaftar dan Berizin di OJK per 20 Desember 2019', <www.ojk.go.id>, dikunjungi pada 15 Januari 2020.

${ }^{5}$ Otoritas Jasa Keuangan 'Siaran Pers: Satgas Waspada Investasi Temukan Lagi 125 Fintech Peer-to-Peer Lending Ilegal dan 182 Entitas Penawaran Investasi Tanpa Izin', 3 Desember 2019, $<$ www.ojk.go.id>, dikunjungi pada 20 Desember 2019.
} 
Informasi yang bernama Asosiasi Fintech Pendanaan Bersama Indonesia (AFPI). AFPI ditunjuk OJK sebagai asosiasi resmi penyelenggara layanan pinjam meminjam uang berbasis teknologi informasi di Indonesia, berdasarkan surat No. S-5/D.05/2019. ${ }^{6}$ Hingga 4 Februari 2019, AFPI beranggotakan 99 penyelenggara Fintech P2P Lending yang sudah terdaftar dan berizin di OJK. Contoh penyelenggara fintech P2P Lending yang tidak mensyaratkan adanya jaminan kebendaan adalah Investree dan Modalku.

Perkembangan fintech yang cukup pesat di Indonesia, menjadi fokus pemerintah untuk segera membuat peraturan yang baru. Saat ini pemerintah telah mengeluarkan beberapa regulasi yang mengatur tentang Layanan Pinjam Meminjam Uang Berbasis Teknologi Informasi, diantaranya:

1. Peraturan Otoritas Jasa Keuangan Nomor 77/POJK.01/2016 Tentang Layanan Pinjam Meminjam Uang Berbasis Teknologi Informasi;

2. Peraturan Otoritas Jasa Keuangan Nomor 13/POJK.02/2018 Tentang Inovasi Keuangan Digital di Sektor Jasa Keuangan;

3. Surat Edaran Otoritas Jasa Keuangan Nomor No.18/SEOJK.02/2017 Tentang Tata Kelola dan Manajemen Risiko Teknologi Informasi;

4. Surat Edaran Otoritas Jasa Keuangan Nomor 21/SEOJK.03/2017 Tentang Penerapan Manajemen Risiko dalam Penggunaan Teknologi Informasi Oleh Bank Umum;

5. Peraturan Bank Indonesia Nomor 19/12/PBI/2017 Tentang Penyelenggaraan Teknologi Finansial;

6. Surat Edaran Bank Indonesia Nomor 18/22/DKSP perihak Penyelenggaraan Layanan Keuangan Digital;

Objek jaminan meskipun bersifat opsional, hal tersebut tidak mengurangi kewajiban penyelenggara fintech menerapkan prinsip kehati-hatian. Kewajiban tersebut diatur dalam Peraturan Bank Indonesia Nomor 19/12/PBI/2017 Tentang Penyelenggaraan Teknologi Finansial yang mengharuskan penyelenggara fintech memperhatikan Prinsip Perlindungan Konsumen serta manajemen risiko dan kehati-hatian. $^{7}$

${ }^{6}$ AFPI, 'Tentang AFPI' <www.afpi.or.id>, dikunjungi pada 13 Januari 2020.

${ }^{7}$ Anisa Rahma Dita Dwinanda, 'Penerapan Prinsip Kehati-Hatian Dalam Layanan Pinjam Meminjam Uang Berbasis Teknologi Informasi Pada Situs Uangteman.Com’ (2019) 2 JuristDiction.[10]. 
Credit Scoring digunakan untuk membedakan kualitas debitor dari segi kuantitatif dan kualitatif. ${ }^{8}$ Kriteria Credit Scoring yang diterapkan oleh satu Penyelenggara dapat berbeda dari Penyelenggara lainnya, hal ini tergantung dari persyaratan yang ditetapkan oleh masing-masing Penyelenggara. Dalam Credit Scoring Penyelenggara dapat menetapkan jumlah pinjaman yang dapat diberikan kepada Debitor serta bunga kredit yang berbeda sesuai risiko debitor. Beberapa faktor yang menjadi penentu Credit Scoring antara lain domisili, jumlah penghasilan, track record, kondisi keuangan, dan ada atau tidaknya jaminan kebendaan dari debitor. Faktor yang paling berpengaruh terhadap Credit Scoring adalah keberadaan atas jaminan kebendaan dari Debitor, sebab dengan adanya jaminan maka akan menjamin pelunasan utang karena Kreditor dapat melakukan eksekusi atas jaminan kebendaan apabila Debitor wanprestasi.

Saat ini di Indonesia belum ada aturan yang secara khusus mengatur tentang Credit Scoring. Dengan tidak adanya aturan tersebut maka tidak ada standard khusus bagi Penyelenggara untuk menetapkan kriteria apa saja yang wajib dipenuhi di dalam Credit Scoring. Hal tersebut menimbulkan kurangnya perlindungan hukum bagi Kreditor apabila Penyelenggara P2P Lending tidak mempunyai standard khusus dalam Credit Scoring-nya. Dengan demikian, terdapat kerancuan atas seleksi performa Debitor yang dapat mengakibatkan potensi wanprestasi menjadi lebih besar.

\section{Kriteria Kelayakan Credit Scoring oleh Penyelenggara dalam Layanan Pinjam Meminjam Uang Berbasis Teknologi Informasi}

Jenis risiko yang khusus terdapat dalam Layanan Pinjam Meminjam Uang Berbasis Teknologi Informasi diatur dalam Pasal 21 POJK No. 77/POJK.01/2016 Tentang Layanan Pinjam Meminjam Uang Berbasis Teknologi Informasi. Risiko tersebut dibagi menjadi dua macam:

1. Risiko Operasional;

2. Risiko Kredit.

${ }^{8}$ ibid. 
Saat ini OJK mewaspadai empat risiko khusus yang mungkin terjadi dalam Layanan Pinjam Meminjam Uang Berbasis Teknologi Informasi. Risiko pertama adalah risiko diserang peretas. Kedua, risiko gagal bayar bagi fintech yang bisnisnya menjadi perantara, contohnya P2P Lending. Risiko yang ketiga adalah risiko penipuan. Risiko yang terakhir yaitu penyalahgunaan data klien. ${ }^{9}$ Risikorisiko tersebut termasuk kedalam Risiko Operasional dan Risiko Kredit seperti yang diatur dalam Pasal 21 POJK No. 77/POJK.01/2016 Tentang Layanan Pinjam Meminjam Uang Berbasis Teknologi Informasi.

Penyelenggara melakukan berbagai macam cara untuk menerapkan manajemen risiko. Salah satu penerapan yang paling penting untuk mencegah terjadinya risiko adalah dengan penilaian risiko (risk assesment). Dalam penilaian risiko (risk assesment) Penyelenggara melakukan identifikasi pengukuran, pemantauan, dan pengendalian risiko. Dalam penilaian risiko (risk assesment) Penyelenggara menggunakan sebuah sistem yang dikenal sebagai Credit Scoring.

Credit Scoring adalah sistem yang dipakai oleh suatu lembaga pembiayaan / bank termasuk Penyelenggara Layanan Pinjam Meminjam Uang Berbasis Teknologi Informasi dalam menentukan kelayakan calon Debitor untuk menerima pinjaman. ${ }^{10}$ Melalui Credit Scoring, Penyelenggara mengumpulkan data sekaligus melakukan profiling calon Debitor untuk menilai kelayakan pengajuan kredit yang diajukan oleh calon Debitor. Hal yang harus diperhatikan dalam Credit Scoring adalah, Penyelenggara harus bersikap jujur dan tidak boleh memanipulasi data calon Debitor, karena hal tersebut akan berdampak pada jumlah kredit yang diberikan tidak sebanding dengan potensi risiko kredit macet. Penyelenggara dalam Credit Scoring wajib menelusuri riwayat transaksi Debitor seperti riwayat pembayaran kredit yang tepat atau tidak, dan banyaknya kredit yang sedang dimiliki Debitor saat sedang mengajukan kredit kepada fintech lending. Atas dasar tersebut, Credit

\footnotetext{
${ }^{9}$ Dinda Audriene dan Christine Novita Nababan, “OJK Waspadai Empat Risiko Bisnis Fintech", <www.cnnindonesia.com>, dikunjungi pada 13 Oktober 2019.

${ }^{10}$ Niko Ramadhani, 'Pentingnya Mengetahui Apa Itu Kredit Scoring', <www.akseleran. co.id>, 16 Oktober 2018, dikunjungi 11 Oktober 2019.
} 
Scoring menjadi salah satu faktor penting yang harus diperhatikan oleh fintech lending untuk membantunya melakukan penilaian risiko kredit.

Credit Scoring memiliki setidaknya tujuh fungsi utama dalam membantu proses penilaian risiko kredit. Tujuh fungsi tersebut adalah sebagai berikut: ${ }^{11}$

1. Streamline the lending process (Menyederhanakan proses peminjaman);

2. Improve loan officer efficiency (Meningkatkan efektifitas petugas kredit);

3. Increase the consistency of the evaluation process (Meningkatkan konsistensi dari proses evaluasi);

4. Reduce human bias in the lending decision (Mengurangi kesalahan manusia dalam pengambilan keputusan peminjaman);

5. Enable the bank to vary the credit policy according to risk classification, such as underwriting or monitoring some lower risk loans without on-site business inspections (Memungkinkan bank untuk memvariasikan kebijakan kredit sesuai dengan klasifikasi risiko, seperti penjaminan emisi atau pemantauan beberapa pinjaman berisiko rendah tanpa inspeksi bisnis di tempat);

6. Better quantify expected losses for different risk classes of borrowers (Perhitungan jumlah kemungkinan kerugian untuk kelas risiko yang berbeda dari peminjam); and

7. Reduce time spent on collections, which in some markets claim up to 50 percent of loan officers' time (Mengurangi waktu yang dihabiskan untuk koleksi, dimana di beberapa penyedia pinjaman mengklaim hingga 50 persen waktu dari petugas kredit (ACCION, Credit Scoring for Microenterprise Brief, www.accion.org).

Perbedaan antara analisis Prinsip 5C, 7P dan 3R pada Perbankan dengan Credit Scoring pada Layanan Pinjam Meminjam Uang Berbasis Teknologi Informasi dapat dilihat melalui tabel berikut:

Tabel 1. Perbandingan antara Analisa Prinsip 5C 7P dan 3R pada Perbankan dengan Credit Scoring pada LPMUBTI

\begin{tabular}{|c|c|c|c|c|}
\hline No. & Keterangan & \multicolumn{2}{|c|}{$\begin{array}{c}\text { Analisa Prinsip 5C, 7P dan 3R } \\
\text { pada Perbankan }\end{array}$} & Credit Scoring pada LPMUBTI \\
\hline 1. & Character & Melalui Interview & & Hanya melalui KTP \\
\hline 2. & Capacity & $\begin{array}{l}\text { Calon Debitor } \\
\text { menyertakan slip gaji }\end{array}$ & Wajib & $\begin{array}{l}\text { Pada kredit jumlah tertentu Calon } \\
\text { Debitor tidak perlu menyertakan } \\
\text { slip gaji }\end{array}$ \\
\hline 3. & Capital & $\begin{array}{l}\text { Melakukan survey } \\
\text { harta benda Debitor }\end{array}$ & terhadap & $\begin{array}{l}\text { Tidak melakukan survey terhadap } \\
\text { harta benda Debitor }\end{array}$ \\
\hline
\end{tabular}

${ }^{11}$ Dean Caire, et all, 'A Handbook for Developing Credit Scoring Systems in A Microfinance Context'(DAI Washington 2006).[1]. 


\begin{tabular}{|c|c|c|c|}
\hline 4. & Condition & $\begin{array}{l}\text { Tunduk pada POJK yang } \\
\text { berkaitan dengan Perbankan }\end{array}$ & $\begin{array}{l}\text { Tunduk pada POJK yang berkaitan } \\
\text { dengan LPMUBTI dan LJKNB }\end{array}$ \\
\hline 5. & Collateral & Mayoritas ada & Mayoritas tidak ada \\
\hline 6. & Party & Mengetahui loyalitas Debitor & Tidak mengetahui loyalitas Debitor \\
\hline 7. & Purpose & $\begin{array}{l}\text { Mengetahui tujuan pasti } \\
\text { pengajuan kredit oleh Calon } \\
\text { Debitor }\end{array}$ & $\begin{array}{l}\text { Tidak mengetahui tujuan pasti } \\
\text { pengajuan kredit oleh Calon Debitor }\end{array}$ \\
\hline 8. & Prospect & Ada survey prospek usaha & Tidak ada survey prospek usaha \\
\hline 9. & Payment & $\begin{array}{l}\text { Mengetahui segala sumber dana } \\
\text { calon Debitor }\end{array}$ & $\begin{array}{l}\text { Hanya mengetahui sumber dana } \\
\text { melalui gaji dan omzet usaha tanpa } \\
\text { mengetahui sumber lain }\end{array}$ \\
\hline 10. & Profitability & $\begin{array}{l}\text { Mengetahui perkembangan } \\
\text { kemampuan dari calon Debitor }\end{array}$ & $\begin{array}{l}\text { Tidak mengetahui perkembangan } \\
\text { kemampuan dari calon Debitor }\end{array}$ \\
\hline 11. & Protection & Ada & Mayoritas tidak ada \\
\hline 12. & Return & Ada kontrol khusus & $\begin{array}{l}\text { Tidak ada kontrol khusus, hanya } \\
\text { berdasarkan data yang dikirim } \\
\text { melalui website fintech lending }\end{array}$ \\
\hline 13. & Repayment & Ada kontrol khusus & $\begin{array}{l}\text { Tidak ada kontrol khusus, } \\
\text { hanya berdasarkan data yang } \\
\text { dikirim melalui website fintech } \\
\text { lending }\end{array}$ \\
\hline 14. & $\begin{array}{l}\text { Risk Bearing } \\
\text { Activity }\end{array}$ & Ada kontrol khusus & $\begin{array}{l}\text { Tidak ada kontrol khusus, hanya } \\
\text { berdasarkan data yang dikirim } \\
\text { melalui website fintech lending }\end{array}$ \\
\hline
\end{tabular}

Perlu dipahami bahwa di negara lain, misalnya seperti China, telah menggunakan sistem yang disebut dengan Credit Profile disamping penggunaan Credit Scoring. Di dalam Credit Profile Penyelenggara ketika telah menyetujui kredit yang diajukan Debitor, selanjutnya mengamati performa dari Debitor selama jangka waktu kredit. Dari performa Debitor tersebut dapat menentukan apakah risk grade nya sesuai atau tidak dan dapat berubah, sehingga Credit Profile sebenarnya lebih fair untuk Debitor karena Penilaian Debitor tidak terbatas pada data-data yang diberikan namun juga melihat dari kemauan dan itikad baik dari Debitor untuk melakukan pelunasan utang. Meskipun demikian, sistem Credit Profile masih belum diterapkan pada fintech P2P Lending di Indonesia. 


\section{Eksistensi Jaminan dalam Penentuan Kriteria Kelayakan Credit Scoring dalam Layanan Pinjam Meminjam Uang Berbasis Teknologi Informasi}

Istilah jaminan merupakan terjemahan dari istilah zekerheid atau cautie, yaitu kemampuan Debitor untuk memenuhi atau melunasi perutangannya kepada Kreditor, yang dilakukan dengan cara menahan benda tertentu yang bernilai ekonomis sebagai tanggungan atas pinjaman atau utang yang diterima Debitor terhadap Kreditornya. ${ }^{12}$ Mariam Darus Badrulzaman merumuskan jaminan sebagai suatu tanggungan yang diberikan oleh seorang Debitor dan/atau pihak ketiga kepada Kreditor untuk menjamin kewajibannya dalam suatu perikatan.

Tidak ada ketentuan yang memberikan definisi dari jaminan umum secara tersurat, melainkan definisi tersebut tersirat dalam ketentuan Pasal 1131 BW yang menyatakan: "Segala barang-barang bergerak dan tak bergerak milik debitur, baik yang sudah ada maupun yang akan ada, menjadi jaminan untuk perikatan-perikatan perorangan debitur itu". Dari ketentuan Pasal 1131 BW tersebut memberikan definisi bahwa jaminan umum adalah jaminan yang disediakan oleh undang-undang yang demi hukum akan berusaha meliput risiko tidak dipenuhinya prestasi yang bersangkutan oleh salah satu pihak dalam perikatan. ${ }^{13}$

Kedudukan Kreditor dengan jaminan umum adalah sebagai Kreditor Konkuren. Akibat hukumnya adalah terdjadi persamaan kedudukan terhadap harta Debitor dan tidak ada yang diutamakan dalam pelunasan, sekalipun mereka memiliki tagihan yang lebih dulu. Hal ini diatur dalam Pasal 1132 BW yang menyatakan:

"Barang-barang itu menjadi jaminan bersama bagi semua kreditur terhadapnya hasil penjualan barang-barang itu dibagi menurut perbandingan piutang masing-masing kecuali bila diantara para kreditur itu ada alasan-alasan sah untuk didahulukan".

Jaminan umum tersebut dalam prakteknya kurang efektif dalam mengatasi risiko yang timbul. Kelemahan tersebut antara lain: ${ }^{14}$

\footnotetext{
${ }_{12}$ Rachmadi Usman, Hukum Jaminan Keperdataan (Sinar Grafika 2009).[66].

${ }^{13}$ Moch. Isnaeni, Pengantar Hukum Jaminan Kebendaan (Laksbang PRESSIndo 2016).[45-

${ }^{14}$ Trisadini Prasastinah Usanti dan Leonora Bakarbessy, Hukum Jaminan (Revka Petra Media
} 46]. 2016).[15]. 
1. Hanya berkedudukan sebagai Kreditor Konkuren;

2. Hak yang lahir adalah hak perorangan yang bersifat relatif;

3. Kreditor tidak mengetahui secara pasti berapa banyak dan berapa nilai dari seluruh harta kekayaan dari Debitor;

4. Kreditor tidak mengetahui secara pasti berapa banyak Kreditor yang dimiliki oleh Debitor;

5. Ada kalanya hasil lelang dari penjualan jaminan umum tidak mencukupi baik karena jumlah pinjaman yang lebih besar atau karena banyaknya Kreditor yang memperebutkan hasil lelang.

Kreditor jika menginginkan posisi yang lebih baik, maka sebaiknya jangan sekedar mengandalkan jaminan umum dalam Pasal 1131 BW, melainkan harus berusaha membuat calon Debitor menyertakan jaminan khusus yang dibuat dalam suatu perjanjian jaminan khusus guna membangun benteng yang ganda agar Kreditor memiliki posisi yang lebih tangguh dan aman. ${ }^{15}$

Sesuai Penggolongannya, perjanjian jaminan khusus terdapat dua macam yaitu Perjanjian Jaminan Perorangan dan Perjanjian Jaminan Kebendaan. Perjanjian Jaminan Perorangan terjadi kalau ada pihak ketiga yang bersedia menjadi penanggung (borg) utang Debitor dan atas dasar kesepakatan Kreditor yang dibuat dalam suatu perjanjian dengan nama Perjanjian Penanggungan (borgtocht). ${ }^{16}$ Berdasarkan Pasal 1821 BW yang menyatakan bahwa tiada suatu Perjanjian Penanggungan apabila tidak ada Perjanjian Pokoknya, maka Perjanjian Penanggungan adalah Perjanjian Tambahan (accessoir). Akibat hukumnya adalah, jika Perjanjian Pokoknya (biasanya utang piutang) berakhir, maka berakhir pula Perjanjian Penanggungan tersebut. Sifat Perjanjian Tambahan (accessoir) juga melekat pada Perjanjian Jaminan Kebendaan.

Hak kebendaan memiliki ciri-ciri sebagai berikut: ${ }^{17}$

1. Hak mutlak, yaitu dapat dipertahankan terhadap siapapun, tidak sekedar pada rekan sekontraknya saja tapi juga kepada pihak-pihak lain yang mungkin di kemudian hari ikut terkait.

2. Droit de suite, yaitu hak kebendaan akan tetap mengikuti bendanya ke tangan

\footnotetext{
${ }^{15}$ Moch. Isnaeni, Op.Cit.[91].

${ }^{16}$ ibid. [92].

${ }^{17}$ Trisadini Prasastinah Usanti, Agus Yudha Hernoko, Erni Agustin, Buku Ajar: Hukum Perdata (Airlangga University Press 2012).[44].
} 
siapapun benda itu berada. Hak kebendaan melekat pada bendanya sehingga kalau berpindah tangan yang bersangkutan akan terkena pula untuk wajib menghormatinya.

3. Asas Prioritas, yaitu hak kebendaan yang lahir terlebih dahulu diutamakan dibandingkan yang lahir kemudian. Pemegang hak kebendaan yang lahir terlebih dahulu akan dibayar paling awal, sedangkan yang belakang harus menunggu yang ada di depannya. Asas Prioritas berlaku apabila terjadi benturan antara pemegang hak kebendaan dengan pemegang hak kebendaan.

4. Droit de preference, yaitu adanya preferensi (Pasal 1133 BW) bahwa pihak yang memiliki hak kebendaan dalam hal pelunasan utang harus lebih didahulukan pembayarannya, seketika kalau benda yang dijadikan objek hak kebendaan laku dalam pelelangan. Asas ini berlaku apabila terjadi benturan antara kreditor pemegang hak kebendaan (Kreditor Preference) dengan Kreditor Konkuren.

5. Gugat Kebendaan, yaitu pemegang hak kebendaan mempunyai macam-macam actie jika terdapat gangguan atas haknya misalnya dengan penuntutan kembali, gugatan untuk menghilangkan gangguan atas haknya, gugatan untuk pemulihan dalam keadaan semula. Sebagaimana hak yang dimiliki seorang pemilik dengan melakukan gugatan revindikasi berdasarkan Pasal 574 BW.

Jaminan kebendaan memiliki fungsi yang sangat penting dalam Layanan Pinjam Meminjam Uang Berbasis Teknologi Informasi. Untuk lebih jelasnya dapat dilihat melalui tabel berikut:

Tabel 2. Risk Grade apabila terdapat Jaminan Kebendaan (Agunan) ${ }^{18}$

\begin{tabular}{|c|c|c|c|}
\hline & $\begin{array}{l}\text { Rating } \\
\text { Pinjaman }\end{array}$ & $\begin{array}{l}\text { Suku } \\
\text { Bunga }\end{array}$ & $\begin{array}{c}\text { Agunan/ } \\
\text { Tanpa Agunan }\end{array}$ \\
\hline \multirow{9}{*}{$\begin{array}{l}\text { Resiko } \\
\text { semakin } \\
\text { rendah }\end{array}$} & $\mathrm{A}++$ & $11.75 \%$ & Beragunan \\
\hline & $A+$ & $12.25 \%$ & Beragunan \\
\hline & A & $12.75 \%$ & Beragunan \\
\hline & A- & $13.25 \%$ & Beragunan \\
\hline & $\mathrm{B}++$ & $15.75 \%$ & Beragunan \\
\hline & $\mathrm{B}+$ & $16.75 \%$ & Beragunan \\
\hline & $\mathrm{B}$ & $17.75 \%$ & Beragunan \\
\hline & B- & $19.00 \%$ & Beragunan/Tanpa Agunan \\
\hline & $\mathrm{C}++$ & $24.00 \%$ & Beragunan/Tanpa Agunan \\
\hline \multirow{2}{*}{$\begin{array}{l}\text { Resiko } \\
\text { semakin } \\
\text { tinggi }\end{array}$} & $C+$ & $27.00 \%$ & Beragunan/Tanpa Agunan \\
\hline & C & $30.00 \%$ & Beragunan/Tanpa Agunan \\
\hline
\end{tabular}

Akibat hukum apabila terdapat jaminan kebendaan adalah rating pinjaman akan menjadi lebih baik, sehingga jumlah pinjaman dapat maksimal dan suku bunganya

${ }^{18}$ Niko Ramadhani, "Pentingnya Mengetahui Apa Itu Kredit Scoring", <www.akseleran. co.id>, dikunjungi 31 Oktober 2019. 
lebih rendah. Kreditor berkedudukan sebagai Kreditor Preference yang memiliki hak untuk didahulukan dalam pembayaran serta upaya hukum yang dimiliki Kreditor apabila Debitor wanprestasi adalah eksekusi jaminan kebendaan. Akibat hukum apabila tidak terdapat jaminan kebendaan adalah rating pinjaman akan menjadi lebih rendah, sehingga jumlah pinjaman tidak dapat maksimal dan suku bunganya tentu akan lebih tinggi, karena risiko lebih tinggi. Kreditor berkedudukan sebagai Kreditor Konkuren yang mengakibatkan Debitor tidak memiliki hak untuk didahulukan dalam pembayaran, dan upaya hukum apabila Debitor wanprestasi adalah gugatan wanprestasi ke Pengadilan, hal tersebut kurang efektif dalam pelunasan utang Debitor.

\section{Kesimpulan}

Salah satu cara manajemen risiko yang diterapkan Penyelenggara adalah dengan menggunakan sistem Credit Scoring. Sistem Credit Scoring mempunyai fungsi utama untuk menentukan calon Debitor layak atau tidak untuk menerima kredit. Kriteria kelayakan Credit Scoring memiliki perbedaan dengan Analisa Prinsip 5C 7P dan 3R dalam perbankan. Hal paling mendasar yang membedakan Credit Scoring P2P Lending dengan Analisa Prinsip 5C 7P dan 3R pada perbankan adalah mayoritas tidak mensyaratkan adanya jaminan kebendaan / no collateral. Hasil dari Credit Scoring adalah risk grade. Contoh fintech lending yang menerapkan Credit Scoring adalah Investree dan Modalku, yang masing-masing memiliki kriteria yang berbeda. Hingga saat ini tidak ada aturan yang secara khusus mengatur tentang Credit Scoring.

Dalam Kriteria Kelayakan Credit Scoring, Jaminan memiliki fungsi yamg penting dalam menentukan risk grade calon Debitor. Hal tersebut dikarenakan jaminan dapat meminimalisir risiko yang terjadi apabila Debitor wanprestasi dan memberikan perlindungan hukum bagi Penyelenggara dan Kreditor. Akibat hukum apabila terdapat jaminan kebendaan dalam Layanan Pinjam Meminjam Uang Berbasis Teknologi Informasi adalah risk grade pinjaman akan semakin baik dan suku bunganya akan menjadi lebih rendah. Kedudukan Kreditor yang 
dalam hal ini diwakili oleh Penyelenggara sebagai kuasanya berkedudukan sebagai Kreditor Preference. Akibat hukum apabila tidak terdapat jaminan kebendaan dalam Layanan Pinjam Meminjam Uang Berbasis Teknologi Informasi adalah risk grade pinjaman akan semakin rendah dan suku bunganya akan menjadi lebih tinggi. Kedudukan Kreditor yang dalam hal ini diwakili oleh Penyelenggara sebagai kuasanya berkedudukan sebagai Kreditor Konkuren. Oleh karena, tidak ada jaminan khusus maka yang berlaku adalah jaminan umum dalam Pasal $1131 \mathrm{BW}$. Upaya hukum yang dapat dilakukan oleh Kreditor untuk memperoleh pelunasan utang adalah melakukan gugatan wanprestasi ke Pengadilan Negeri dengan gugatan ganti rugi melalui harta benda Debitor secara umum, namun hal tersebut cenderung memerlukan proses yang lama dan kurang efektif dalam memperoleh pelunasan utang dari Debitor.

Penyelenggara dalam melakukan profiling calon Debitor melalui sistem Credit Scoring seharusnya melakukan analisa yang lebih mendalam terhadap karakteristik serta kemampuan dari calon Debitor. Penyelenggara perlu untuk melakukan survey secara langsung mengenai identitas, watak, dan track record dari calon Debitor, karena jika hanya dengan KTP belum cukup untuk mengetahui apakah calon Debitor memiliki itikad baik atau tidak. Selain itu Penyelenggara juga perlu untuk melakukan survey terhadap kemampuan finansial dari calon Debitor, sebab jika hanya melihat slip gaji atau data yang dikirimkan melalui webiste fintech lending kurang memberikan kepastian hukum kepada Kreditor tentang kemampuan calon Debitor untuk melunasi utang. Hal tersebut diperlukan untuk memberikan perlindungan hukum kepada Kreditor dan mencegah agar Debitor tidak wanprestasi, karena yang berlaku adalah jaminan umum. Jika yang berlaku adalah jaminan umum, maka dalam pelunasan utang bagi Kreditor cenderung kurang efektif.

OJK dalam memberikan izin terhadap fintech lending harus lebih selektif, terutama dalam hal Credit Scoring yang wajib dilakukan Penyelenggara dalam Layanan Pinjam Meminjam Uang Berbasis Teknologi Informasi. Peraturan yang ada saat ini yaitu POJK No. 77/POJK.01/2016 Tentang Layanan Pinjam Meminjam Uang Berbasis Teknologi Informasi dan SEOJK No.18/SEOJK.02/2017 Tentang 
Tata Kelola dan Manajemen Risiko Teknologi Informasi hanya memberikan poin-poin yang wajib dipenuhi tanpa disertai kewajiban yang harus diterapkan Penyelenggara secara konkret. Untuk mewujudkan perlindungan hukum yang lebih maksimal, OJK harus segera mengeluarkan peraturan yang secara khusus mengatur tentang Credit Scoring. Diharapkan dengan adanya peraturan tersebut membuat Penyelenggara memiliki sistem Credit Scoring yang lebih menjamin perlindungan hukum bagi Kreditor yang telah mempercayakan dananya kepada Penyelenggara, mengingat mayoritas Layanan Pinjam Meminjam Uang Berbasis Teknologi Informasi tidak mensyaratkan adanya jaminan kebendaan sebagai pelunasan utang.

\section{Daftar Bacaan}

\section{Buku}

Dean Caire, et all, A Handbook for Developing Credit Scoring Systems in A Microfinance Context, (DAI Washington 2006).

Freedman Roy S., Introduction to Financial Technology (Elsevier 2006).

Moch. Isnaeni, Pengantar Hukum Jaminan Kebendaan (Laksbang PRESSIndo 2016).

Rachmadi Usman, Hukum Jaminan Keperdataan (Sinar Grafika 2009).

Trisadini Prasastinah Usanti, Agus Yudha Hernoko, Erni Agustin, Buku Ajar: Hukum Perdata (Airlangga University Press 2012).

Trisadini Prasastinah Usanti dan Leonora Bakarbessy, Hukum Jaminan (Revka Petra Media 2016).

\section{Jurnal}

Anisa Rahma Dita Dwinanda, 'Penerapan Prinsip Kehati-Hatian Dalam Layanan Pinjam Meminjam Uang Berbasis Teknologi Informasi Pada Situs Uangteman. Com' (2019) 2 Jurist-Diction.

Candrika Radita, 'Tanggung Gugat Penyelenggara Peer to Peer Lending Jika Penerima Pinjaman Melakukan Wanprestasi' (2018), 1 Jurist-Diction. 


\section{Laman}

Abdul Rasyid, 'Sekilas Perkembangan Fintech di Indonesia' (Binus 2019), <www. law.binus.ac.id>, dikunjungi pada 25 Juni 2019.

AFPI, 'Tentang AFPI', <www.afpi.or.id>, dikunjungi pada 13 Januari 2020.

Dinda Audriene dan Christine Novita Nababan, 'OJK Waspadai Empat Risiko Bisnis Fintech', <www.cnnindonesia.com>, 19 April 2016, dikunjungi pada 13 Oktober 2019.

Niko Ramadhani, 'Pentingnya Mengetahui Apa Itu Kredit Scoring', <www. akseleran.co.id>, 16 Oktober 2018, dikunjungi 31 Oktober 2019.

Otoritas Jasa Keuangan, 'Penyelenggara Fintech Terdaftar dan Berizin di OJK per 20 Desember 2019', <www.ojk.go.id>, dikunjungi pada 15 Januari 2020.

Otoritas Jasa Keuangan 'Siaran Pers: Satgas Waspada Investasi Temukan Lagi 125 Fintech Peer-to-Peer Lending Ilegal dan 182 Entitas Penawaran Investasi Tanpa Izin', 3 Desember 2019, <www.ojk.go.id>, dikunjungi pada 20 Desember 2019.

\section{Perundang-undangan}

Burgerlijk Wetboek (BW) Staatblad 1847; 23.

Undang-Undang Nomor 7 Tahun 1992 Tentang Perbankan (Lembaran Negara Republik Indonesia Tahun 1992 Nomor 31, Tambahan Lembaran Negara Republik Indonesia Nomor 3472).

Undang-Undang Nomor 4 Tahun 1996 Tentang Hak Tanggungan atas Tanah Beserta Benda-Benda yang Berkaitan Dengan Tanah (Lembaran Negara Republik Indonesia Tahun 1996 Nomor 42, Tambahan Lembaran Negara Republik Indonesia Nomor 3632).

Undang-Undang Nomor 42 Tahun 1999 Tentang Jaminan Fidusia (Lembaran Negara Republik Indonesia Tahun 1999 Nomor 168, Tambahan Lembaran Negara Republik Indonesia Nomor 3889).

Undang-Undang Nomor 10 Tahun 1998 Tentang Perubahan atas UndangUndang Nomor 7 Tahun 1992 Tentang Perbankan (Lembaran Negara Republik Indonesia Tahun 1998 Nomor 182, Tambahan Lembaran Negara Republik Indonesia Nomor 3790).

Undang-Undang Nomor 21 Tahun 2011 Tentang Otoritas Jasa Keuangan (Lembaran 
Negara Republik Indonesia Tahun 2011 Nomor 111, Tambahan Lembaran Negara Republik Indonesia Nomor 5253).

Undang-Undang Nomor 19 Tahun 2016 Tentang Perubahan Atas UndangUndang Nomor 11 Tahun 2008 Tentang Informasi dan Transaksi Elektronik (Lembaran Negara Republik Indonesia Tahun 2016 Nomor 251, Tambahan Lembaran Negara Republik Indonesia Nomor 5952).

Peraturan Pemerintah Nomor 82 Tahun 2012 Tentang Penyelenggaraan Sistem dan Transaksi Elektronik (Lembaran Negara Republik Indonesia Tahun 2012 Nomor 189, Tambahan Lembaran Negara Republik Indonesia Nomor 5348).

Peraturan Otoritas Jasa Keuangan Nomor No./POJK.05/2015 Tentang Penerapan Manajemen Risiko Bagi Lembaga Jasa Keuangan Non-Bank (Lembaran Negara Republik Indonesia Tahun 2015 Nomor 69, Tambahan Lembaran Negara Republik Indonesia Nomor 5682).

Peraturan Otoritas Jasa Keuangan Nomor 18/POJK.03/2016 Tentang Penerapan Manajemen Risiko bagi Bank Umum (Lembaran Negara Republik Indonesia Tahun 2016 Nomor 53, Tambahan Lembaran Negara Republik Indonesia Nomor 5861).

Peraturan Otoritas Jasa Keuangan Nomor 38 /POJK.03/2016 Tentang Penerapan Manajemen Risiko dalam Penggunaan Teknologi Informasi oleh Bank Umum (Lembaran Negara Republik Indonesia Tahun 2016 Nomor 267, Tambahan Lembaran Negara Republik Indonesia Nomor 5963).

Peraturan Otoritas Jasa Keuangan Nomor 77/POJK.01/2016 Tentang Layanan Pinjam Meminjam Uang Berbasis Teknologi Informasi (Lembaran Negara Republik Indonesia Tahun 2016 Nomor 324, Tambahan Lembaran Negara Republik Indonesia Nomor 6005).

Peraturan Otoritas Jasa Keuangan Nomor 13/POJK.02/2018 Tentang Inovasi Keuangan Digital di Sektor Jasa Keuangan (Lembaran Negara Republik Indonesia Tahun 2018 Nomor 135, Tambahan Lembaran Negara Republik Indonesia Nomor 6238).

Peraturan Bank Indonesia Nomor 18/17/PBI/2016 Tentang Uang Elektronik (Lembaran Negara Republik Indonesia Tahun 2016 Nomor 179, Tambahan Lembaran Negara Republik Indonesia Nomor 5925).

Peraturan Bank Indonesia Nomor 18/40/PBI/2016 Tentang Penyelenggaraan Pemrosesan Transaksi Pembayaran (Lembaran Negara Republik Indonesia Tahun 2016 Nomor 236, Tambahan Lembaran Negara Republik Indonesia Nomor 5945). 
Peraturan Bank Indonesia Nomor 19/12/PBI/2017 Tentang Penyelenggaraan Teknologi Finansial (Lembaran Negara Republik Indonesia Tahun 2017 Nomor 245, Tambahan Lembaran Negara Republik Indonesia Nomor 6142).

Surat Edaran Otoritas Jasa Keuangan Nomor 21/SEOJK.03/2017 Tentang Penerapan Manajemen Risiko dalam Penggunaan Teknologi Informasi oleh Bank Umum.

Surat Edaran Otoritas Jasa Keuangan Nomor No.18/SEOJK.02/2017 Tentang Tata Kelola dan Manajemen Risiko Teknologi Informasi.

Surat Edaran Bank Indonesia Nomor 18/22/DKSP perihal Penyelenggaraan Layanan Keuangan Digital. 
1888 Nalendra Pradipto: Fungsi Jaminan Sebagai...

--halaman ini sengaja dibiarkan kosong-- 